Riga, Latvia, November 20, 2020

\title{
PERFORMANCE BUDGETING IN UKRAINE: ASSESSING AND ANALYSING THE BUDGET PROGRAM EFFICIENCY
}

\section{Margaryta Ambarchian ${ }^{1}$}

DOI: https://doi.org/10.30525/978-9934-26-002-5-24

Performance budgeting may be referred to as a method for preparing the budgets by public authorities based on the comparison of results already achieved in the area of rendering the public services and amounts of resources involved for attaining these results.

A number of economists have been examined matters related to implementing the performance budgeting in governance practices of European countries and evaluating the budget programs by state and local authorities. It is worth mentioning scientific papers of D. Moynihan, I. Beazley, M. de Jong, L. Hawke, F. Mordacq, R. Raudla, and E. Vaksova [1], R. Mussari, A. E. Tranfaglia, C. Reichard, H. Bjørnå, V. Nakrošis, and S. Bankauskaitè-Grigaliūnienė [2], D.-J. Kraan, L. von Trapp, V. Kostyleva, J. van Tuinen, and M. Morgner [3].

Ensuring the transparency of using the budgetary funds for the intended purpose and enhancing the level of control over outcomes of executing the budget program are pivotal goals of the conception of performance-based budgeting applied in the budget process of Ukraine. To control outcomes of executing the budget program, the Ministry of Finances of Ukraine requires key spending units to compile reports on executing the budget program, which contain target and factual performance indicators for corresponding budget programs. Analytical tools, approved by the Ministry of Finances of Ukraine, provide doing the comprehensive analysis of quantitative indicators and evaluating the qualitative indicators of executing the budget program.

The main goals for assessing the budget program efficiency are the following:

- determining the level of efficiency and performance of a particular budget program through establishing an interrelation between achieved results and a used amount of budgetary funds;

- ascertaining the extent of attaining a target and accomplishing the budget program's goals through analysing the execution of performance indicators;

- revealing the factors impeding the execution of a budget program and achieving the target performance indicators outlined in a budget program;

\footnotetext{
${ }^{1}$ Kyiv National Economic University Named after Vadym Hetman, Ukraine
} 
- drawing up propositions regarding enhancing the efficiency of using the budgetary funds;

- making managerial decisions aimed at enhancing the efficiency of using the budgetary funds [4].

Information on compiling, executing, analysing, and assessing a budget program is set out in the following documents and reports:

a) the Budget Program Passport - a document determining an amount of funds needed to execute a budget program, legal grounds for undertaking a program, a purpose, goals, directions of activities, persons in charge, performance indicators, and miscellaneous characteristics of a budget program. Data from the passport enable government officials to exercise the control over the use of budgetary funds and to analyse the budget program efficiency [5];

b) the Report on Executing the Budget Program Passport (the Report on Executing the Budget Program Passport of a Local Budget) is a report, which:

- determines amounts of expenditures according to a budget program;

- determines deviations of amounts of cash expenditures from amounts approved in a budget program passport;

- discloses performance indicators;

- reveals an analysis of performance indicators;

- contains an explanation of deviations between factual performance indicators attained at the expense of cash expenditures and indicators approved in a budget program passport;

- discloses a brief conclusion on the execution of budget program, which encompasses information on the extent of accomplishing the budget program's goals [5];

c) the Result of Analysing the Efficiency of Executing the Budget Program is a document comprising a complex analysis of using the budgetary funds and outcomes achieved by key spending units in the process of undertaking the same budget programs [6];

d) the Results of Assessing the Budget Program Efficiency is a document containing measures for monitoring, analysing, and controlling the target and efficient use of budgetary funds [4].

Stages for assessing the budget program efficiency:

- assessing the budget program efficiency in the process of compiling the budget declaration and the project of the state budget;

- assessing the budget program efficiency in the process of performing the state budget;

- assessing the budget program efficiency for the reporting period.

Results of assessing the budget program efficiency, including conclusions of public authorities, is the ground for making decisions on: 
- amending the budget allocations for the current budget period;

- submitting the corresponding proposals to the project of the budget for the planned budget period;

- submitting the proposals to the forecast of budget for the two budget periods following the planned one;

- submitting the proposals regarding ceasing the implementation of corresponding budget programs [4].

Consequently, information outlined in the considered documents and reports enables governmental officials to ascertain whether local governments and agencies have to continue the implementation of a particular budget program in the subsequent budget periods.

\section{References:}

1. Moynihan, D., Beazley, I., Jong, M. de, Hawke, L., Mordacq, F., Raudla, R., \& Vaksova, E. (2016). Toward Next-Generation Performance Budgeting: Lessons from the Experiences of Seven Reforming Countries. The World Bank. Available at: https://openknowledge.worldbank.org/bitstream/handle/10986/25297/9781464809545. pdf?sequence $=2$

2. Mussari, R., Tranfaglia, A. E., Reichard, C., Bjørnå, H., Nakrošis, V., \& Bankauskaitè-Grigaliūnienè, S. (2016). Design, Trajectories of Reform, and Implementation of Performance Budgeting in Local Governments: A Comparative Study of Germany, Italy, Lithuania, and Norway. In S. Kuhlmann \& G. Bouckaert (Eds.), Local Public Sector Reforms in Times of Crisis. Palgrave Macmillan. https://doi.org/10.1057/978-1-137-52548-2_6

3. Kraan, D.-J., Trapp, L. von, Kostyleva, V., Tuinen, J. van, \& Morgner, M. (2016). Budgeting in Ukraine. OECD Journal on Budgeting, 5, 69-140. Available at: http://gogov.org.ua/wp-content/ uploads/2016/05/Budgeting-in-Ukraine.pdf

4. The Ministry of Finances of Ukraine (2020). Poriadok zdiisnennia otsinky efektyvnosti biudzhetnykh prohram holovnymy rozporiadnykamy koshtiv derzhavnoho biudzhetu : Nakaz Ministerstva finansiv Ukrainy vid 19.05.2020 No. 223 [Guidelines for assessing the budget program efficiency by key spending units of the state budget : the order of the Ministry of Finances of Ukraine of 19.05.2020 No. 223]. Available at: https://zakon.rada.gov.ua/laws/show/z0646-20\#Text

5. The Ministry of Finances of Ukraine (2014). Pravyla skladannia pasportiv biudzhetnykh prohram mistsevykh biudzhetiv ta zvitiv pro yikh vykonannia : Nakaz Ministerstva finansiv Ukrainy vid 26.08.2014 № 836 [Rules for compiling the budget program passports of local budgets and reports on executing the passports : the order of the Ministry of Finances of Ukraine of 26.08.2014 No. 836]. Available at: https://zakon.rada.gov.ua/laws/show/z1104-14\#Text

6. The Ministry of Finances of Ukraine (2013). Udoskonalena metodyka zdiisnennia porivnialnoho analizu efektyvnosti biudzhetnykh prohram, yaki vykonuiutsia rozporiadnykamy koshtiv mistsevykh biudzhetiv: lyst Ministerstva finansiv Ukrainy vid 19.09.2013 № 31-05110-14-5/27486 [Amended guidelines for doing the comparative analysis of the budget program efficiency conducted by spending units of 
local budgets : the letter of the Ministry of Finances of Ukraine of 19.09.2013 No. 31-05110-14-5/27486]. Available at: https://www.ibser.org.ua/sites/default/files/ lyst_mfu_vid_19.09.2013_udoskonalena_metodyka.pdf

\section{CONCEPTUAL FUNDAMENTALS OF TRAINING BUSINESS SPECIALISTS OF THE HOSPITALITY INDUSTRY IN HIGHER EDUCATION INSTITUTIONS OF UKRAINE}

\section{Liudmyla Batchenko ${ }^{1}$ \\ Liliia Honchar ${ }^{2}$}

DOI: https://doi.org/10.30525/978-9934-26-002-5-25

Modern Ukrainian society is in a complex transformational process of various transformations, including educational ones. The humanitarian development of modern Ukrainian society poses new challenges to the domestic education system, the solution of which is ineffective within the existing methodology. Today, the issue of analyzing higher education systems and its compliance in the field of training specialists of various profiles to real time and changing processes in various spheres of society is quite relevant.

The dependence of the competitiveness of the functioning of higher education institutions of Ukraine on the transformational educational processes requires from all subjects of educational activity initiative actions to design mechanisms for radical reform of the entire system of higher education. Transformational processes affecting all aspects of the country's life raise before the education system the issue of changing the educational model, which will expand the concept of humanitarian training.

At the scientific and theoretical level there is a need to introduce scientific and organizational support for an integrative and innovative approach to the process of training students of various specialties for creative industries, including 028 «Management of socio-cultural activities» 241 «Hotel and restaurant business», 242 «Tourism».

In turn, the scientific and organizational support of the integrativeinnovative approach to professional training of students provides a scientific and methodological level of relevance of this problem. The discrepancy between the scientific-theoretical and scientific-practical levels of training of future specialists for the hospitality industry of Ukraine identified in general

\footnotetext{
${ }^{1}$ Kyiv National University of Culture and Arts, Ukraine

${ }^{2}$ Kyiv National University of Culture and Arts, Ukraine
} 